\title{
Delivery of stem cells to the brain: potential for treatment of neurodegenerative disease
}

\author{
Alison Burgess", Isabelle Aubert, Kullervo Hynynen \\ From Current and Future Applications of Focused Ultrasound 2014. 4th International Symposium \\ Washington, D.C, USA. 12-16 October 2014
}

\section{Background/introduction}

Stem cell therapy is a promising strategy to treat neurodegenerative diseases, including Alzheimer's and Parkinson's diseases. However, for stem cell therapy to be considered for clinical use, new delivery methods need to be developed. We have used focused ultrasound (FUS) as a method to induce transient opening of the blood-brain barrier (BBB) to promote the passage of therapeutic stem cells into the brain.

\section{Methods}

As a proof of principle study to demonstrate the application of this therapeutic strategy for Parkinson's disease, we targeted the striatum using magnetic resonance imaging (MRI) for BBB opening. Definity microbubble contrast agent was injected intravenously at the onset of FUS application using a $558 \mathrm{kHz}$ transducer $(\sim 0.3 \mathrm{MPa}$ estimated in situ pressure, $10 \mathrm{~ms}$ bursts, $1 \mathrm{~Hz}$ pulse repetition frequency, $120 \mathrm{~s}$ total exposure duration).

\section{Results and conclusions}

During FUS application, neural stem cells expressing green-fluorescent protein (GFP) and labeled with superparamagnetic iron oxide (SPIO) were injected into the carotid artery. Follow up contrast enhanced MR imaging confirmed the opening of the BBB and at $24 \mathrm{hrs}$, MRI was used to detect the SPIO labeled stem cells in the region of interest. After sacrifice, GFP expressing cells were present in the targeted regions of the brain and expressed a neuronal phenotype indicative of their survival post-delivery through the BBB. Histological analysis showed some red blood cell extravasation but there was no evidence of brain tissue damage due to FUS treatment. Together, these data suggest that FUS is an efficient method for delivery of stem cells to the brain and may be the key to

Sunnybrook Research Institute, Toronto, Ontario, Canada reducing the risks of cell transplantation helping to move stem cell therapy forward.

Published: 30 June 2015

doi:10.1186/2050-5736-3-S1-017

Cite this article as: Burgess et al:: Delivery of stem cells to the brain: potential for treatment of neurodegenerative disease. Journal of Therapeutic Ultrasound 2015 3(Suppl 1):017.
Submit your next manuscript to BioMed Central and take full advantage of:

- Convenient online submission

- Thorough peer review

- No space constraints or color figure charges

- Immediate publication on acceptance

- Inclusion in PubMed, CAS, Scopus and Google Scholar

- Research which is freely available for redistribution 